were mailed, bringing to a close the Fall cycle of section newsletter publication.

\section{Headquarters activities}

A new computer and printer have been installed that will primarily be used for $C d R L$ News production. The new equipment will allow magazine production to switch from a dedicated word processing system to microcomputers.

ACRL staff worked on preparing the 1989 budget for approval at the Midwinter Conference.

JoAn Segal and Mary Ellen Davis served on the ALA Word Processing Task Force and helped to develop a policy for ALA on hardware and soft- ware configurations.

ALA staff heard a presentation on the implications of the new tax law with regard to associations, including rules for the deduction of professional expenses for travel to meetings.

ACRL staff worked on the 1989 Operating Plan. A draft was sent to the Planning Committee for discussion at the Midwinter Meeting.

President Joanne Euster planned a Leadership meeting for ACRL Board members and guests for Midwinter and has set up several other opportunities for member leaders to obtain help with their duties and responsibilities. - JoAn S. Segal, ACRL Executive Director.

\title{
Six percent and other standards
}

\author{
By Steve Marquardt \\ Director of Libraries \\ University of Wisconsin-Eau Claire
}

\section{Getting from the real to the ideal.}

\begin{abstract}
W riting in the November 1987 issue of $C \triangleleft R L$ News, J. Richard Madaus appeals to "professional ethic" to argue for a bigger slice of the academic budget. Madaus states that professional ethics should extend "to the basic level of the acceptance or rejection of the conditions and circumstances under which we as professionals will allow ourselves to work." He suggests that at the point of interviewing and being hired, each librarian should raise the ACRL academic library budget standard of $6 \%$ of campus educational and general $(\mathrm{E} \& \mathrm{G})$ funding: "Our national standards will be credible only when every librarian applying for every job brings them up before they are hired."
\end{abstract}

${ }^{1}$ J. Richard Madaus, "Academic Library Funding and Professional Ethics," CひRL News 48 (November 1987):606-609.
Madaus is correct that the "immediate results would be a lot of unfilled positions," because many institutions restrict their support of the library to an amount closer to one half of $6 \%$. An even more immediate result would be exclamations from administrators that such a standard is unrealistic and unaffordable. (Indeed, are there libraries out there still enjoying $6 \%$ of E\&G?) Administrators would label such a standard as self-serving, and would ask why $6 \%$ is necessary.

For the librarian, this $6 \%$ is an ideal resource input, but for the academic administrator, it is an inconveniently large expenditure output. Such an abrupt demand, unjustified by anything other than a self-set standard, will seem less like ethics or even academic politics, but rather more like greed. It may even seem downright unethical, in the sense that "behavior becomes unethical when it favors a 
special interest out of proportion to, and without consideration for, the interests of society as a whole."2

An answer in terms of "lots of neat stuff," from bibliographic instruction to staying on the leading edge of new technology, is not likely to be successful if standard services and resources are already provided at less than $6 \%$ of E\&G. If those activities are now being provided at less than $6 \%$, then why should a $6 \%$ level of support be considered a realistic standard or a necessary ideal?

If such contemporary standard services and resources have never been supported, then education of the administrator must begin immediately. Education of administrators, like all education, takes time. The means too that education is not the shock value of the $6 \%$ standard, which leaps too far from fiscal reality to fiscal ideal. Instead that education must begin with the fundamentally necessary and professionally standard working conditions upon which we should insist. These conditions, which will help us build a budget approaching $6 \%$, and a program of services to match it, can be found among the other ACRL standards for college libraries. They include objectives developed by consensus, collection measurement, staff services and, most important in my view, administrative involvement.

"Standard 1: Objectives" calls for a statement of library objectives, developed in consultation with representatives of the teaching faculty, administrators and students. This will help to build a broadly based consensus about the level of services to be provided, an important requirement in a time when some provosts are encouraging chargebacks to control the growth of services. ${ }^{3}$ The specific channel for this consensus-building consultation may be important. A college library committee reporting to an academic officer is redundant of the normal reporting line to the chief librarian. It may be-and here is a subject for research-more fruitful, although at times more aggravating, if the library committee were part of the faculty senate, thus promoting routine consideration of library matters in the deliberative body of the entire faculty.

"Standard 2: Collections" contains quantitative measures which can be applied to the resources and curriculum of the institution, encouraging the investment of funds to correct inadequacies.

A quantitative analysis of "Standard 4: Staff" will beg questions of what is not being done in the

2"Ethics in America," Leadership 3 (September 1980):11-12, as quoted in Kenneth G. Peterson, "Ethics in Academic Librarianship: The Need for Values," Journal of Academic Librarianship 9 (July 1983):132.

${ }^{3}$ See the remarks of Maurice Glicksman, provost and dean of faculty at Brown University, in Martha Morss, "A Provost Looks at Library Costs and Charges," Research Libraries in OCLC: A Quarterly 16 (Spring 1985):3. way of "Standard 5: Services." What gaps exist in the library's service profile, in terms of reference service, instruction, interlibrary loans, hours, database searching, photocopy services, and provision of and help with newer technologies and formats?

The key to progress toward meeting these standards is contained in "Standard 7: Administration," specifically 7.2: "The library director shall be an officer of the college and shall report to the president or the chief academic officer of the institution." Just as important, in my view, is presence on the central academic governing council of the campus, such as the council of deans or the president's cabinet. This presence alone will not be sufficient to obtain all needed resources, but it is necessary for the education of administrators who will benefit from regular discussion of the role of the library and the changing nature of academic library services.

Presence of the librarian in the central administrative body is necessary for the timely receipt of information, the formulation and sharing of educational ideas and initiatives on the campus, the trading of favors, rolling of logs, and the crafting of criteria and priorities for budgets and programs with due consideration of library services and those who use them. As campus leaders give periodic informed consideration to library services, then working conditions become increasingly "ethical," in the sense that "ethical behavior recognizes, and resides within, a shared interest."5

The unfortunate reality is that the isolation of the library from the rest of the academic organization has been a too prevalent feature of large universities as well as small colleges. While at Columbia University, Patricia Battin observed that "the most striking feature of traditional academic organizations, and the one which I believe is most misunderstood and ignored by our academic colleagues, is the virtual isolation of the library in the organization. Despite rhetoric about it being 'the heart of the university,' the library and librarians have been for years isolated from the policy councils of most institutions." 6

The "Standards for College Libraries" are silent about library membership on the central academic governing council. Perhaps smaller colleges lack enough academic deans to constitute a "council." Or is the direct reporting line to the chief academic officer meant to assume participation in the governance body? This assumption is often unwarranted. The next edition of the standards should incorporate the stronger recommendation contained in the "Standards for University Libraries": "Because it is closely related to instruction and re-

\footnotetext{
4"Standards for College Libraries, 1986,” C $b R L$ News 47 (March 1986): 189-200.

"Ethics in America," 132.

${ }^{6}$ Patricia Battin, "The Library: Center of the Restructured University,” C $b R L 45$ (May 1984): 170.
} 
search, the university library should be formally recognized as one of the major academic units within the university, and its chief administrative officer should participate regularly and directly in university-wide academic planning and decisionmaking."

Some university presidents would expand the presence of librarians into still more campus groups. As President of the University of Wisconsin System, Robert M. O'Neil recommended that "committees which advise on fiscal and budget decisions should routinely have library membership... The review of both present and proposed degree programs must include an assessment of library resources and the implications. In these and perhaps other ways, meaningful participation of the library in university governance can be enhanced." $"$

The presence of the librarian on these influential groups is a necessary, but not sufficient, condition for success in the struggle to provide library users

\footnotetext{
7 "Standards for University Libraries," $C \& R L$ News 40 (April 1979): 105.

${ }^{8}$ Robert M. O'Neil, "Academic Libraries and the Future: A President's View," CむRL 45 (May 1984):187.
}

with needed services and materials. In these councils, the librarian must reiterate the "shared interest" which is the basis of ethical behavior. In these committees, councils and cabinets, power and ethics meet in the shared interests of those present.

The question of how uninvolved librarians negotiate or otherwise secure membership on these groups is not addressed by our professional literature. What are the realities of actual experience in the negotiating process at and after the point of being interviewed and hired? Beyond that "day one," what is the role of power in the struggle for resources, between librarians and administrators? What is the correlation between the number of minutes spent annually with presidents, provosts and deans, and the percent of E\&G allocated to the Library?

Answers to these questions could serve as rungs on the ladder to the level of support required for services which truly would be up to standard. The economic criteria of $6 \%$ of E\&G can neither be won nor retained without the political strength to make it happen. The administrative involvement recommended in the existing standards must be honored first. Only then will the economic resources follow.

\section{ACRL staff profile}

Mary Ellen K. Davis, program officer in charge of a wide range of ACRL activities, has been on the staff since November 1985 . She was previously employed at ALA as assistant director for "Let's Talk About It," a reading and discussion program sponsored by the Association of Specialized and Cooperative Library Agencies and funded by the National Endowment for the $\mathrm{Hu}-$ manities.

Davis' responsibilities in ACRL include providing advisory services and managing the nonserial publications pro-

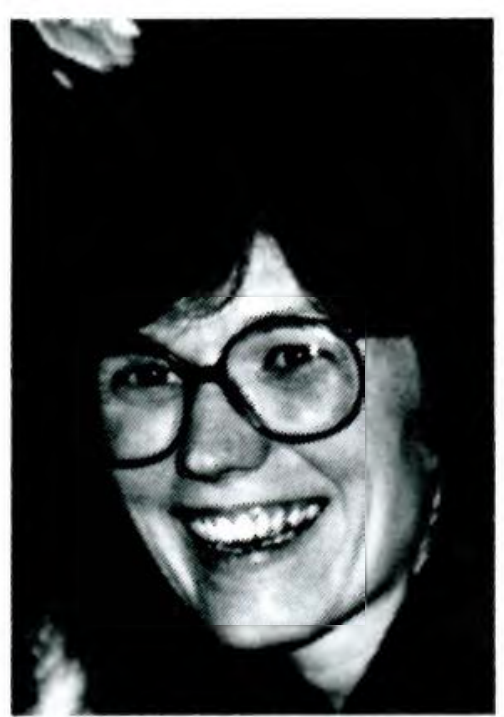

Mary Ellen Davis gram of the division. She serves as liaison to several committees including Publications, and Standards and Accreditation, and coordinates the ACRL awards program. Davis also works with members on the annual RBMS preconference, the BIS preconfercnce, and the President's Program.

Among ongoing responsibilities, Davis oversees the international exchange program and a library statistics data collection effort, and is now working with the Performance Measures Committee (ad hoc).

Prior to coming to ALA Davis was a reference librarian at Central Michigan University and at the Downers Grove, Illinois, Public Library. She earned bachelor's and MLS degrees from the University of Illinois at Urbana-Champaign and a master's degree in education from Central Michigan University, and taught elementary school before entering the library profession.

\section{Letter}

\section{9th-century academic libraries}

\section{To the Editor:}

I read with great interest David Kaser's article on "19th-century Academic Library Buildings" in the September 1987 issue of $C \& R L$ News. In it he asked for reader assistance and comments about his research. I am currently preparing a monograph on rural New England academic libraries. If any readers could help in locating information, anecdotes, drawings, or photos, please write me at San Jose State University Library, One Washington Square, San Jose, CA 95192-0028. - Ruth Hafter, Library Director. 


\section{ACQUISITION PERSPECTIVES}

1. ANY BOOK IN PRINT .

means delivery to your library of all available books from any publisher or distributor in the U.S. or Canada. There is no list of publishers you must check ... WE DELIVER THEM ALL . . . including trade, scientific/technical, text, university presses, paperbacks, associations, small presses, Canadian, and software.

Send us your direct orders and experience the "added value" received when using Book House.

\section{ANY BOOK IN PRIN}

\section{IN THE UNITED STATES} AND CANADE

BOOK HOUSE

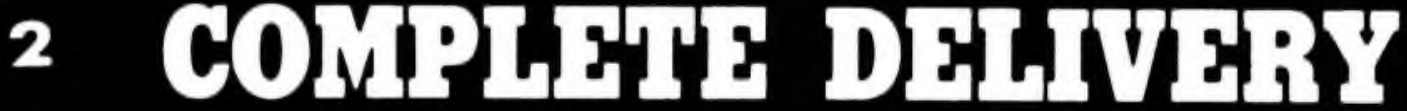

\section{OPHN ORDAR RHPORTS}

4 ACCURATH BOOR DATHस?

CALL TOLL-FREE TODAY

1-800-248-1146

In Canada \& Michigan

CALL COLLECT (517) 849-2117

OCLC Vendor No. 17397

SAN 169-3859

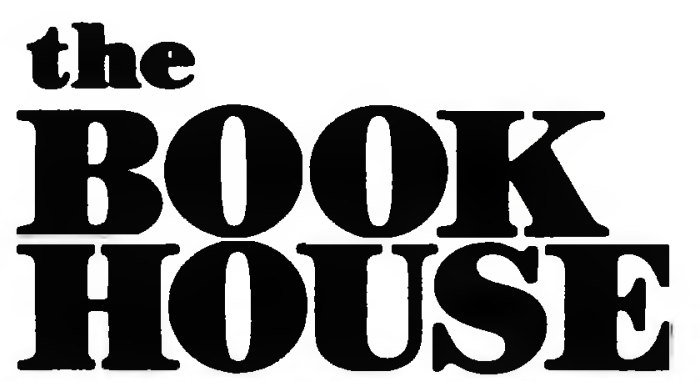

JOBBERS SERVING LIBRARIES WITH ANY BOOK IN PRINT SINCE 1962 208 WEST CHICAGO STREET JONESVILLE, MICHIGAN 49250 